9. White MC, Lynch P. Blood contact and exposures among operating room personnel: a multicenter study. Am J Infect Control 1993;21:243-248.

10. Wright JG, McGeer AJ, Chyatte D, Ransohoff DE Exposure rates to patients' blood for surgical personnel. Surgery 1993;114:897-901.

11. Shadduck PF, Tyler DS, Lyerly HK, et al. Commercially available surgical gowns do not prevent penetration by HIV-1. Surgical Forum 1990:41:77-80.

12. Smith JD, Nichols RJ. Barrier efficacy of surgical gowns. Arch Surg 1991;26:756-761.

13. Brown PL. What's new in ASTM's test methods for liquid and viral resistance? Materials Management in Healthcare $1994 ; 3(8): 14$.

14. Selection of Surgical Gowns and Drabes in Healthcare Facilities, TIR1 1-006-MM. Arlington, VA: Association for the Advancement of Medical Instrumentation; September 1994.

15. Belkin NL. Letters to the editor. AORN Joumal 1994;60(3):365370.

16. Altman KW, McElhaney JH, Moylan JA, Fitzpatrick KT. Transmural surgical gown pressure measurements in the operating theater. Am /Infect Control 1991;19:147-155.

17. Belkin NL. Surgical pros and cons. Surg Gynecol Obstet 1993;177:514-515.

18. Belkin NL Are new test methods accurate predictors of gowns' protective barrier effectiveness? AORN journal 1994;59(4):897-
899

19. Belkin NL. Cost restraints forcing tough protective equipment choices. Hospital Materials Management 1994;19(5):18

20. Belkin NL. The new American Society for Testing and Materials tests: all that glitters is not gold.Am J Infect Control 1994;22(3):172176.

21. Belkin NL. The challenge of selecting an appropriate protective gown. Today's OR Nurse $1994 ; 16(4): 5-7$.

22. Stull JO. Response. OR Reports July/August 1993;2:10.

23. McCullough EA. Methods for determining the barrier efficacy of surgical gowns. Am J Infect Control 1993;21:368-374.

24. Telford GL, Quebbeman EJ. Assessing the risk of blood exposure in the operating room. Am J Infect Control 1993;21:351-356.

25. Fairchild's Dictionary of Textiles. New York, NY: Fairchild Publications; 1979.

26. International Fabricare Institute Technical Operating Information. Water repellents. IFI Fabricare News June 1988.

27. Beck WC. Thermal comfort for the patient during surgery: comfort, a physiological as well as a psychological phenomenon. Gutkrie Journal 1993;62:159-160.

28. Beck WC, Belkin NL, Meyer KK. A new approach to the surgeon's gown. The Guthrie Journal 1994;63(2):73-76.

29. Beck WC, Belkin NL, Meyer KK. Divide and conquer: protection, comfort and cost of the surgeons gown. Am J Surg. In press.

\title{
CDC Announces Availability of Update Epi
}

\section{by Gina Pugliese, RN, MS} Medical News Editor

The Epi Info computer programs produced by CDC and the World Health Organization provide public domain software for word processing, database management, and statistics work in public health. Version 6 of Epi Info recently was released. It features a configurable pull-down menu, facilities for producing and using hypertext (active text), additional statistics, and many programming improvements.

Copies of Epi Info, a 600-page instruction manual, and a companion program for geographic mapping (Epi map) are available from USD Inc., 2075A West Park Place, Stone
Mountain, GA 30087; telephone (404) 469-4098; FAX (404) 469-0681.

Epi Info and Epi Map also are available on the worldwide Internet using the following access information: Site:FTP.CDC.GOV; User ID: Anonymous; Directory for Epi Info:/ PUB/EPI/EPIINFO; Directory or Epi Map:/PUB/EPI/EPIMAP 